\title{
Front Matter: Volume 9955
}

, "Front Matter: Volume 9955," Proc. SPIE 9955, Nonimaging Optics: Efficient Design for Illumination and Solar Concentration XIII-Commemorating the 50th Anniversary of Nonimaging Optics, 995501 (12 December 2016); doi: $10.1117 / 12.2256095$

SPIE Event: SPIE Optical Engineering + Applications, 2016, San Diego, California, United States 


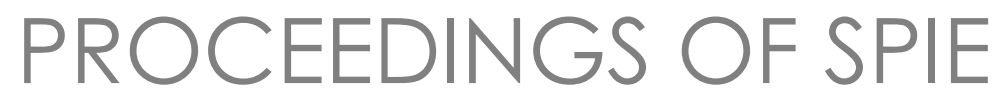

\title{
Nonimaging Optics: Efficient Design for Illumination and Solar Concentration XIII-Commemorating the 50th Anniversary of Nonimaging Optics
}

\author{
Roland Winston \\ Jeffrey M. Gordon \\ Editors
}

28-29 August 2016

San Diego, California, United States

Sponsored and Published by

SPIE 
The papers in this volume were part of the technical conference cited on the cover and title page. Papers were selected and subject to review by the editors and conference program committee. Some conference presentations may not be available for publication. Additional papers and presentation recordings may be available online in the SPIE Digital Library at SPIEDigitallibrary.org.

The papers reflect the work and thoughts of the authors and are published herein as submitted. The publisher is not responsible for the validity of the information or for any outcomes resulting from reliance thereon.

Please use the following format to cite material from these Proceedings:

Author(s), "Title of Paper," in Nonimaging Optics: Efficient Design for Illumination and Solar Concentration XIII-Commemorating the 50th Anniversary of Nonimaging Optics, edited by Roland Winston, Jeffrey M. Gordon, Proceedings of SPIE Vol. 9955 (SPIE, Bellingham, WA, 2016) Sixdigit Article CID Number.

ISSN: 0277-786X

ISSN: 1996-756X (electronic)

ISBN: 9781510603011

ISBN: 9781510603028 (electronic)

Published by

SPIE

P.O. Box 10, Bellingham, Washington 98227-0010 USA

Telephone +1 3606763290 (Pacific Time) · Fax +1 3606471445

SPIE.org

Copyright (C) 2016, Society of Photo-Optical Instrumentation Engineers.

Copying of material in this book for internal or personal use, or for the internal or personal use of specific clients, beyond the fair use provisions granted by the U.S. Copyright Law is authorized by SPIE subject to payment of copying fees. The Transactional Reporting Service base fee for this volume is $\$ 18.00$ per article (or portion thereof), which should be paid directly to the Copyright Clearance Center (CCC), 222 Rosewood Drive, Danvers, MA 01923. Payment may also be made electronically through CCC Online at copyright.com. Other copying for republication, resale, advertising or promotion, or any form of systematic or multiple reproduction of any material in this book is prohibited except with permission in writing from the publisher. The CCC fee code is 0277-786X/16/\$18.00.

Printed in the United States of America.

Publication of record for individual papers is online in the SPIE Digital Library.

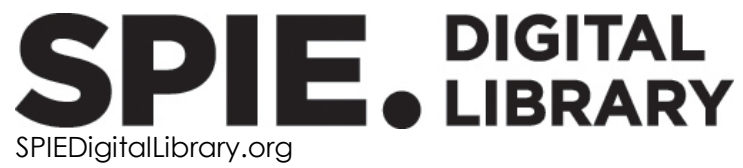

Paper Numbering: Proceedings of SPIE follow an e-First publication model. A unique citation identifier (CID) number is assigned to each article at the time of publication. Utilization of CIDs allows articles to be fully citable as soon as they are published online, and connects the same identifier to all online and print versions of the publication. SPIE uses a six-digit CID article numbering system structured as follows:

- The first four digits correspond to the SPIE volume number.

- The last two digits indicate publication order within the volume using a Base 36 numbering system employing both numerals and letters. These two-number sets start with $00,01,02,03,04$, $05,06,07,08,09,0 A, 0 B \ldots$. OZ, followed by 10-1Z, 20-2Z, etc. The CID Number appears on each page of the manuscript. 


\title{
Contents
}

\author{
$\checkmark \quad$ Authors \\ vii Conference Committee \\ ix The Advanced LIGO detectors in the era of first discoveries (Plenary Paper) [9960-200]
}

SESSION 1 HALF A CENTURY OF NONIMAGING OPTICS

995502 How nonimaging optics began [9955-1]

995504 Retrospective on 30 years of nonimaging optics development for solar energy at the University of Chicago (Invited Paper) [9955-3]

995505 The role of optics in practical concentrating photovoltaics [9955-4]

SESSION 2 SOLAR CONVERSION OPTICS I

995507 3D-printed concentrators for tracking-integrated CPV modules [9955-6]

995508 Improving the effectiveness of photovoltaic devices by light guiding optical foils [9955-7]

SESSION 3 SOLAR CONVERSION OPTICS II

9955 0A Design of a light confining concentrator for a solar photochemical reactor and upper bound to the method [9955-9]

SESSION 4 FREEFORM AND ILLUMINATION OPTICS I

9955 OB Freeform multifocal lenses designed with supporting quadric method (SQM): geometry and diffraction effects (Invited Paper) [9955-10]

\section{SESSION 5 FREEFORM AND ILLUMINATION OPTICS II}

9955 OD Recent advances in the SMS method: diffraction and 3D aplanatism (Invited Paper) [9955-12]

9955 OE Thin direct-lit application for general lighting realized by freeform micro-optical elements [9955-13] 
9955 OG Nonimaging optics in lighting to reduce light pollution [9955-16]

9955 Ol Flow line asymmetric nonimaging concentrating optics [9955-18]

\section{SESSION 7 SOLAR THERMAL CONCENTRATORS}

9955 OK The rise of non-imaging optics for rooftop solar collectors (Invited Paper) [9955-20]

9955 ON Nonimaging optics maximizing exergy for hybrid solar system [9955-23]

POSTER SESSION

995500 Design of a segmented nonimaging Fresnel lens optimized for non-tracking solar collection [9955-24]

9955 OP Modeling of efficient light extraction in light-pipes through specular surfaces with elliptical and lineal front shapes [9955-25] 


\title{
Authors
}

Numbers in the index correspond to the last two digits of the six-digit citation identifier (CID) article numbering system used in Proceedings of SPIE. The first four digits reflect the volume number. Base 36 numbering is employed for the last two digits and indicates the order of articles within the volume. Numbers start with 00, 01, 02, 03, 04, 05, 06, 07, 08, 09, OA, OB...0Z, followed by 10-12, 20-2Z, etc.

\author{
Abbasi, Hamid, ON \\ Abdelhamid, Mahmoud, ON \\ Andersen, Marilyne, OA \\ Apostoleris, Harry, 07 \\ Benitez, P., OD \\ Blakers, Andrew, OK \\ Ceballos-Herrera, Daniel E., 0O, OP \\ Chiesa, Matteo, 07 \\ Cygan, David, ON \\ Elarde, Victor, ON \\ Ferrari, Dave, OK \\ Ferry, Jonathan, OG, ON \\ Grabovickic, D., OD \\ Hartmann, Paul, OE \\ Horne, S., 05 \\ Jiang, Lun, OG, OI, ON \\ Karamata, Boris, $\mathrm{OA}$ \\ Kirk, Alexander, ON \\ Kozlov, Alexandr, ON \\ Kuna, Ladislav, OE \\ Leiner, Claude, 08, 0E \\ Leland, Julian, 07 \\ Martínez-Guerra, Edgar, 00, OP \\ Mendes-Lopes, J., OD \\ Miñano, Juan C., OD \\ Narasimhan, B., OD \\ Nemitz, Wolfgang, OE \\ Nikolic, M., OD \\ O'Gallagher, Joseph J., 04 \\ Oliker, Vladimir, OB \\ Osowski, Mark, ON \\ Peharz, G., 08 \\ Ratcliff, Tom, OK \\ Reil, Frank, OE \\ Ricketts, Melissa, OG \\ Rosengarten, Gary, OK \\ Sánchez-Guerrero, Guillermo E., 00, OP \\ Schweitzer, Susanne, OE \\ Sommer, Christian, 08, OE \\ Sigg, Daniel, ix \\ Stanley, Cameron, OK \\ Stefancich, Marco, 07 \\ Viera-González, Perla M., 00, OP \\ Wenzl, Franz P., 08, 0E \\ Widyolar, Bennett K., ON \\ Winston, Roland, 02, 0G, OI, ON
}


Proc. of SPIE Vol. $9955995501-6$

Downloaded From: https://www.spiedigitallibrary.org/conference-proceedings-of-spie on 25 Apr 2023 Terms of Use: https://www.spiedigitallibrary.org/terms-of-use 


\section{Conference Committee}

Program Track Chairs

José Sassián, College of Optical Sciences, The University of Arizona (United States)

R. John Koshel, College of Optical Sciences, The University of Arizona (United States)

Conference Chairs

Roland Winston, University of California, Merced (United States)

Jeffrey M. Gordon, Ben-Gurion University of the Negev (Israel)

Conference Program Committee

Pablo Benítez, CeDInt-UPM (Spain) and Light Prescriptions Innovators LLC (United States)

William J. Cassarly, Synopsys, Inc. (United States)

Daniel Feuermann, Ben-Gurion University of the Negev (Israel)

Juan Carlos Miñano, CeDInt-UPM (Spain) and Light Prescriptions Innovators LLC (United States)

Narkis E. Shatz, SureFire, LLC (United States)

Session Chairs

1 Half a Century of Nonimaging Optics

Daniel Fevermann, Ben-Gurion University of the Negev (Israel)

2 Solar Conversion Optics I

Gary Rosengarten, RMIT University (Australia)

3 Solar Conversion Optics II

Juan Carlos Miñano, CeDInt-UPM (Spain) and Light Prescriptions Innovators LLC (United States)

4 Freeform and Illumination Optics I

Juan Carlos Miñano, CeDInt-UPM (Spain) and Light Prescriptions Innovators LLC (United States)

5 Freeform and Illumination Optics II

Vladimir I. Oliker, Emory University (United States)

6 Novel Optics and Core Concepts

Manuel Collares-Pereira, Universidade de Évora (Portugal) 


\section{Solar Thermal Concentrators \\ Jeffrey M. Gordon, Ben-Gurion University of the Negev (Israel)}

Proc. of SPIE Vol. $9955995501-8$

Downloaded From: https://www.spiedigitallibrary.org/conference-proceedings-of-spie on 25 Apr 2023 Terms of Use: https://www.spiedigitallibrary.org/terms-of-use 